УДК: 616.758.3:616.72-089.87

DOI.ORG/10.37647/0132-2486-2020-106-3-63-70

\title{
ACL Reconstruction: Problems, History and Future. Part II
}

\author{
Zazirnyi I.M. ${ }^{1}$, Kostrub O.O. ${ }^{2}$ \\ ${ }^{1}$ Clinical Hospital "Feofaniya" of the Agency of State Affairs, Kyiv \\ ${ }^{2}$ SI "Institute of Traumatology and Orthopedics of NAMS of Ukraine", Kyiv
}

\begin{abstract}
Summary. Anterior cruciate ligament (ACL) injury is one of the most commonly seen injuries in sport and has a devastating influence on patients' activity levels and quality of life. For patients, whose bistory and results of physical examination suggest an ACL injury, MRI is indicated to confirm the diagnosis and to determine whether there are concomitant injuries. There are limited data of the need for immediate ACL reconstruction. Surgeons need to discuss with the patient the option of a structured accelerated course of rebabilitation as an alternative to immediate reconstruction. If an initial strategy of rebabilitation was chosen, serial evaluation of knee function and functional recovery in the first 3 months after the injury would recommend. If there is residual instability (greater than grade 2) at the time of subsequent assessment, the surgery is necessary to avoid further damage to the articular cartilage and meniscus. When reconstruction is advised as the correct management of an ACL injury, there are various options. The type of a graft, single-bundle or double-bundle reconstruction, graft placement, and whether to use the transtibial, far anteromedial portal, or tibial tunnel-independent technique are choices that must be made. Each option has its own advantages and disadvantages, with singleor double-bundle strategy, proper placement of grafts, and the use of autografts affect the clinical outcome and quality of life of patients. The selection of the best autograft tissue type remains controversial, with the patellar tendon (PT), the hamstring (HS) tendon, and the quadriceps tendon each having their proponents.
\end{abstract}

Key words: anterior cruciate ligament; arthroscopy; reconstruction; treatment.

\section{Introduction}

Anterior cruciate ligament (ACL) ligament injuries of the knee are a common injury in sports medicine. Before advances in arthroscopy and surgical techniques, an ACL damage was considered a career ending injury for many athletes. Since the 1990's, there has been a rapid development of arthroscopic surgery for the ACL and improvement of these techniques. Today's athletes can expect a pre-injury level of stability and function after ACL reconstruction. Procedures have come a long way by learning from both the successes and failures of previous surgical options. ACL injury is one of the most commonly seen injuries in sport and has a devastating influence on activity levels of patients and their quality of life.

\section{Diagnosing Anterior Cruciate Ligament Injuries}

The most common history of an ACL injury may be of a noncontact deceleration, jumping, or cutting action, frequently involving changing direction. This frequently involves rotational maneuvers or lateral bending of the knee into a valgus position with the knee extended and the tibia rotated $[1,2]$. If the ACL injury results from direct contact, present in about one-third of patients, there is often a his- tory of hyperextension or valgus stress on the knee [3]. Post injury swelling of the knee frequently occurs at about 4 hours and aspiration usually reveals hemarthrosis.

Physical examination frequently establishes a diagnosis of ACL injury, especially if the examination is done soon after the injury before swelling, pain, and muscle guarding occurs. Anterior stability of the knee is usually assessed with the Lachman test [4-7]. The Lachman test is usually performed at 20-degree to 30-degree angle of knee flexion while stabilizing the distal femur with one hand. A manual force is then applied to the proximal tibia with the opposite hand, and anterior laxity is assessed the degree of anterior translation of the tibia relative to the femur. This should be compared with the non-injured knee. The Lachman test has been found to have a sensitivity of $85 \%$ and a specificity of $94 \%$ for ACL rupture. The KT 1000 arthrometer (a presurgical and post-surgical tool used to measure anterior-posterior slippage and side-to-side laxity of the knee [8]) has also been used to measure ACL laxity. However, the use of these devices is limited in the acute setting when pain and muscle guarding are present. They may be more valuable to document surgical results both intraoperatively and in the postoperative period. 
Plain radiographs will rule out fractures, loose bodies, degenerative disease, osteophyte formation, and other associated injuries. They may also result in a diagnosis of Segond fracture or avulsion fracture of the lateral capsule, which is pathognomonic of an ACL tear [9]. Using arthroscopy as the gold standard, magnetic resonance imaging (MRI) has a specificity of $95 \%$ and a sensitivity of $86 \%$ for diagnosing ACL injuries [10]. Magnetic resonance imaging is able to visualize both bundles of the native ACL, an important information for surgical reconstruction when the double-bundle technique is used [11-15].

Treatment of Anterior Cruciate Ligament Injuries

Regardless of whether surgical or nonsurgical treatment is ultimately pursued, patients should be advised to ice, compress, elevate, and limit the use of the injured knee immediately after the injury. If the injury to the ACL also affects the associated structures within the knee, including the menisci, PCL, medial collateral ligament, or lateral collateral ligament, surgical reconstruction is needed.

\section{Nonsurgical (Conservative) Management of Anterior Cruciate Ligament Injuries \\ Nonoperative therapy involves 3 months of supervised} physiotherapy; anti-inflammatory medications; range-ofmotion training; gradual strengthening of the quadriceps, hamstrings, hip abductors, and core muscles; and a progressive return to activity. Reevaluation is recommended 6 to 12 weeks after the initial injury to assess the effectiveness of rehabilitation and to consider the need for delayed ACL reconstruction. Functional braces have not been shown to provide adequate restoration of stability [19].

Some patients with ACL injuries may not be candidates for surgery because of serious comorbid medical conditions including serious cardiac, renal, or hepatic disease or because they no longer wish to participate in strenuous physical activities. For individuals who optimal for conservative treatment, physical therapy with an experienced physical therapist or athletic trainer aimed at strengthening the muscles around the knee, especially the quadriceps femoris and hamstring muscles, is pursued. However, without surgical repair, the knee generally remains unstable and prone to further injury [14].

Long-term studies have shown that there is a significant increase in rates of damage to menisci and articular cartilage associated with delayed reconstruction. The rate of healing for meniscal tears is faster when performed at the same time as ACL reconstruction as opposed to being performed alone [14]. Generally, about one-third of patients who are selected as suitable for conservative treatment are able to complete the therapy regimen without the need for surgical intervention. However, patients with high level of sports activity show poor results after conservative treatment of ACL ruptures [15-18].

\section{Operative Strategies. Timing of Surgery}

A systematic review that included 3583 patients from observational studies suggested that no statistically significant differences in subjective objective measures of out- comes were related to the timing of ACL surgery [19]. However, the timing of surgery may affect the development and severity of related soft-tissue damage. A retrospective study in which early ACL reconstruction (i.e., within 12 weeks after injury) was compared with later reconstruction showed higher rates of damage to medial meniscal and medial tibiofemoral cartilage in the group receiving later treatment [20].

Similarly, another observational study that included more than 5000 patients showed that the risk of medial meniscal surgery was twice as high when ACL reconstruction was delayed for more than 5 months after injury and six times as high if delayed for more than 1 year; these risks appeared to be greater among patients younger than 17 years of age [21]. It has been hypothesized that restoring anterior-posterior and rotatory knee laxity may prevent subsequent instability and resulting damage to articular cartilage, the meniscus, or both.

The American Academy of Orthopaedic Surgeons Evidence-Based Guidelines (Table 1) [22] on the management of ACL injuries recommends 12 weeks of non-operative treatment for acute isolated ACL tear followed by a reevaluation of the need for surgery [21]. When ACL reconstruction is indicated, the guidelines recommend that surgery should be performed within 5 months after injury to avoid recurrent instability and resulting additional damage to the meniscus, articular cartilage, or both [22, 23].

\section{Surgical Management of Anterior Cruciate Ligament Injuries}

Because of the frequent failure of nonsurgical approaches to ACL injuries, surgery remains the treatment of choice in almost all athletes who want to remain active. Unfortunately, surgery is not universally successful. Some problems that have resulted in failed ACL reconstruction are graft impingement on the intercondylar roof, graft tension, non-anatomic femoral and tibial tunnel placement (not reproducing the histological and biomechanical characteristics of the native ligament), and incomplete replication of an intact ACL, in particular omitting reconstruction of the posterolateral (PL) bundle [24]. Despite these efforts, $15 \%$ to $25 \%$ of patients who undergo ACL reconstruction continue to suffer pain and instability in their injured knee.

Often, when reconstruction is performed, there is a piece of the ruptured ACL remaining that can be either removed or left in the knee. If the ligament piece is left in place, it can impact visualization during surgery and possibly impact the quality of the reconstruction. In 1\% to $9.8 \%$ of reconstructions, impingement or a Cyclop-lesion (focal nodule[s] of fibrous tissue sitting in the intercondylar notch anterior to the reconstructed ACL) may occur when parts of the ACL are left [24].

When the ruptured ACL is left in place, mechanoreceptors may help with reinnervation. Sensory neurons involved in kinesthesia may also be preserved in the ruptured ACL. It has been suggested that the ACL functions as a sensory organ not only provide proprioceptive feedback but also initiate protective and stabilizing muscular reflexes. In a study, patients who had 
Summary of the AAOS Evidence-Based Guidelines for the Diagnosis and Treatment of ACL Injury

\begin{tabular}{|c|c|}
\hline Stage of Care & $\begin{array}{l}\text { Strength of } \\
\text { Evidence }\end{array}$ \\
\hline Diagnosis & \\
\hline A relevant history and musculoskeletal examination are effective diagnostic tools for injury of the ACL. & High \\
\hline $\begin{array}{l}\text { MRI is useful for the assessment of ACL injury and concomitant injury to ligaments, } \\
\text { the meniscus, or articular cartilage. }\end{array}$ & High \\
\hline Treatment & \\
\hline $\begin{array}{l}\text { There is limited evidence available to compare the effectiveness of nonoperative treatment } \\
\text { of an ACL tear with reconstruction in patients with recurrent instability, but there is support } \\
\text { for consideration of ACL reconstruction because the procedure reduces pathologic laxity. }\end{array}$ & $\begin{array}{l}\text { Limited } \\
\text { Limited }\end{array}$ \\
\hline There is limited evidence to support nonoperative management for less active patients with less laxity. & High \\
\hline $\begin{array}{l}\text { Either single or doublebundle reconstruction can be used. Outcomes for the procedures } \\
\text { have been shown to be similarly good. }\end{array}$ & High \\
\hline $\begin{array}{l}\text { Autografts of the hamstrings (the tendons of the semitendinosus and gracilis muscles) } \\
\text { and the patellar tendon have been shown to have outcomes that are similarly good. }\end{array}$ & High \\
\hline $\begin{array}{l}\text { Similar outcomes have been reported for autografts and allografts, although the results may } \\
\text { not be generalized to all patients. }\end{array}$ & High \\
\hline
\end{tabular}

undergone surgery 3 months to 3.5 years after the ACL injury had the remainder of the ruptured ACL "adapted to the posterior cruciate ligament and sometimes with scar tissue connected to the femur," whereas the second group had "[free floating] ACL remnants." In the first group, mechanoreceptors of Ruffini and, in 1 patient's specimen, Golgi-like organs were present. In the second group, no significant numbers of mechanoreceptors were found. If reinnervation of the ACL causes restoration of kinesthesia and if ACL remnants can be left without risking impingement in the post reconstruction knee biomechanics, it seems to be of benefit [24].

\section{Graft Selection}

The 2 most commonly used grafts in ACL reconstruction are the patellar tendon (PT) and the 4-strand hamstring (HS) tendon made of gracilis and semitendonosus tendons. Both PT and HS autografts result in a functionally stable knee in more than 95\% of surgeries with a 3\% absolute difference in graft failure: 1.9\% with PT and 4.9\% with HS tendon grafts. Benefits of PT grafts include that they are readily accessible, have good structural fixation properties, and have the potential for tendon-to-bone healing. Detriments include anterior knee pain, loss of sensation, patellar fracture, and inferior patellar contracture, although patellar knee pain has been associated with less aggressive rehabilitation methods and the use of open kinetic chain extension exercises. The use of PT grafts has also been associated with post reconstruction extensor quadriceps weakness [25].
The HS tendon graft with all 4 strands equally tensioned can withstand much greater tension strains than a $10-\mathrm{mm}$ PT graft. Some researchers have found that harvesting HS grafts can severely reduce HS strength and endurance up to 9 months after the surgery $[25,26]$. Hamstring grafts can also be difficult to harvest because graft diameter and lengths are variable. A study of patients determined that HS graft diameter was related to height but not to body mass index. When height decreases below $147 \mathrm{~cm}$ and graft diameter decreases below $7 \mathrm{~mm}$, there is an association between graft strength and its cross-sectional diameter [26].

In a meta-analysis, PT autografts were compared with HS tendon autografts. Using KT-1000 arthrometer testing, statistically significant differences between these graft types were found: the PT group had a 79\% side-to-side difference of $3 \mathrm{~mm}$ compared with $73.8 \%$ for the HS group, leading the authors to conclude that PT autografts led to more stable reconstructed knees than HS tendon grafts. No significant differences between PT and HS grafts were found between the proportion of patients requiring postoperative meniscal surgery, and no statistically significant differences were seen between PT autografts and HS autografts infection rates [14].

Quadriceps tendon grafts used for ACL reconstruction have been associated with significantly less anterior knee pain and graft-site morbidity compared with PT grafts. These grafts are taken from the central third of the quadriceps tendon and are composed of the vastus medialis, vastus intermedius, and rectus femoris, yielding a bilaminar graft. The mean cross-sectional area for a $10-\mathrm{mm}-$ 
wide quadriceps tendon graft is $64 \mathrm{~mm}^{2}$, larger than 37 $\mathrm{mm}^{2}$ for the PT; hence, quadriceps tendon grafts produce a broader anatomic insertion of the reconstructed ACL to the tibia. This can decrease physiologic impingement on the intercondylar notch in full extension of the knee. Quadriceps muscle power is not compromised, despite sacrificing a part of the tendon. Overall, quadriceps tendon grafts have the advantage of ease of excision and are comparable with respect to graft size and strength with both PT and HS grafts [27, 28].

The main advantage of allografts versus autografts is avoidance of donor-site morbidity. Other advantages include savings in operative time of graft harvest, availability of larger grafts, superior cosmesis, and the possibility for multiple ligament reconstructions [29]. Potential disadvantages include delayed graft incorporation, disease transmission, potential immune reactions, altered mechanical properties caused by sterilization, and cost of the allograft [30]. Of primary concern is whether allografts are less stable than autografts [29-31]. A recent meta-analysis found that allografts failed 3 times more frequently than autografts [29]. However, a recent study found that autografts and nonirradiated (vs radiated or chemically processed) allografts had similar side-to-side differences of $3 \mathrm{~mm}$ according to the KT-2000 arthrometer [31].

\section{Single-Bundle Versus Double-Bundle Reconstruction}

Between 10\% and 30\% of patients reported persistent instability in their reconstructed knee after single-bundle surgery. This resulted in a return-to-sport rate of only $60 \%$ to $70 \%$ for single-bundle restorations. Single-bundle reconstruction can restore anterior-posterior knee stability but produces knees that are unable to resist combined rotatory loads and do not have normal rotational kinematics [32,33]. Double-bundle restored knees are better at resisting extrinsic forces placed on the knee [34-40]. Although the doublebundle technique is better at restoring normal knee kinematics, there are some disadvantages. It is more difficult to perform surgically and could be the cause of reconstruction failures due to the improper positioning of bone tunnels.

\section{Graft Placement}

Placement of grafts can have a major impact on the clinical outcome of ACL reconstruction. Impossibility to regain full flexion postoperatively can be caused by high graft tension during extension of the knee, which in turn may cause the graft to stretch. This may occur when the ACL graft is placed vertically at the apex of the notch, with the tibial tunnel being in a vertical orientation at an angle 70 degrees from the medial joint line of the tibia and the femoral tunnel and then drilled through that tibial tunnel. Prevention of PCL impingement can be achieved by 3 different techniques: widening the notch so that the space between the PCL and lateral femoral condyle exceeds the diameter of the graft by $1 \mathrm{~mm}$, constructing the tibial tunnel at an angle of 60 to 65 degrees with respect to the medial joint line of the tibia, which moves the femoral tunnel farther down the sidewall and decreases the risk of PCL impingement, and making certain that the lateral edge of the tibial tunnel is placed through the tip of the lateral tibial spine. There is no consensus on the amount of ligament tensioning or the optimal knee flexion angle. Some surgeons prefer to set the tension of the anteromedial (AM) bundle in moderate flexion and the posterolateral (PL) bundle near full extension. The preference for tensioning angles mirrors the position of the bundles to provide the greatest strength when at the most tension in intact knees [38, 39].

\section{Femoral Tunnel Drilling Techniques}

There are different techniques for creating the femoral tunnel [38]. The transtibial technique (drilling through the tibial tunnel) and the far anteromedial portal technique (drilling through the far anteromedial tunnel) are frequently used in ACL surgeries to create a femoral bone tunnel for the AM and PL graft in double-bundle reconstructions.

Although both are commonly used, the far anteromedial portal approach makes it easier to access the femoral footprint of the AM and PL bundles. This is because unlike the transtibial technique, the placement of the femoral tunnel is not limited by the site or angulation of the tibial tunnel. For the far anteromedial portal procedure, the PL bundle tunnel should be drilled at a knee position of 110 degrees of extension to avoid damage to the subchondral bone, cartilage of the lateral femoral condyle, and peroneal nerve [38]. For the transtibial technique, the knee should be flexed at 90 degrees for drilling of the femoral bone tunnel [36]. For the transtibial technique, the graft bending angle of the AM and PL bundles are considerably larger than that of the far anteromedial portal technique at low flexion angles when the graft is fully stretched. Nishimoto et al. believe that the far anteromedial portal technique can produce a more obtuse bending angle at the femoral tunnel in comparison to the transtibial technique and that the former approach might reduce the abrasive stress at this position in anatomic double-bundle ACL reconstructions [38].

Recently, investigators from Duke have emphasized the importance of placing the ACL graft within the ACL footprint on the femur to restore normal joint kinematics $[41,42]$. In the tibial tunnel-independent technique, the graft is placed closer to the center of the native ACL attachment compared with the transtibial technique. Using MRI of 8 patients in each group, the transtibial technique placed the tunnel center on average $9 \mathrm{~mm}$ from the center of the ACL attachment, compared with $3 \mathrm{~mm}$ for the tibial tunnel-independent technique [41]. In another study, the same group used MRI and biplanar fluoroscopy to compare 12 patients where the graft was placed near the antero-proximal border of the ACL and 10 patients where the graft was placed near the center of the ACL [42]. Grafts placed antero-proximally on the femur were longer and more vertical than the native ACL, whereas anatomically placed grafts more closely mimicked ACL motion and length in the contralateral knee. 


\section{Postoperative Rehabilitation}

Goals of postoperative rehabilitation are to restore normal joint motion and strength to the reconstructed knee while protecting the graft [43]. As a consequence of improvements in surgical techniques, graft selection, and fixation methods, rehabilitation programs have changed in recent years to permit immediate weight bearing, early range of motion (within 1-2 weeks after the surgery), and earlier return to sports (usually not before 6 months or until there is return of at least $80 \%$ of thigh strength and the ability to do sport specific agility drills). However, too early return to sports activities may result in graft failure and decisions regarding when to return to sports activities should be based on the functional assessment rather than on time from ACL reconstruction [43]. Generally, in the rehabilitation program, closed kinematic chain exercises to strengthen the hamstring and quadriceps are started early [44]. Closed kinematic chain exercises are those in which the foot is in contact with a solid surface such as with squats and leg presses. Open kinematic chain exercises, in which the foot is not in contact with a solid surface, such as those using leg extension, are considered less safe in the postoperative period and should be added no sooner than 6 weeks after the surgery. Postoperative rehabilitation should also include exercises to enhance core strength, balance, and proprioception [45].

\section{Future Directions}

Future directions in ACL injury research will seek to improve all aspects of care of the patient with an ACL injury. Research in interface tissue engineering aims to improve the regeneration of tissue interfaces to improve the fixation of soft tissue grafts by devising a new generation of integrative fixation devices for soft tissue repair [46]. Freeze-dried allografts offer potential advantages including limited immunogenicity, ease of graft storage, and the potential for improved biological function [47]. Plateletrich plasma has the potential to speed recovery after ACL reconstruction by improving autograft maturation, donorsite morbidity, pain control, and allograft incorporation [48]. Other future developments in ACL reconstruction may include repair of the injured ACL and newer synthetic replacement grafts [49]. Whether the potential benefits currently ascribed to each of the above areas will be borne out, remains to be determined.

\section{Conclusion}

For the patients, whose history and results of physical examination suggest an ACL injury, MRI is indicated to confirm the diagnosis and to determine whether there are concomitant injuries or not.

Given the limited data showing that immediate ACL reconstruction and initial rehabilitation followed by surgery (if needed) are associated with similar outcomes in such patients, you need to discuss with the patient the option of a supervised, structured, accelerated course of rehabilitation as an alternative to immediate reconstruction. If an initial strategy of rehabilitation is chosen, serial evaluation of knee function and functional recovery in the first 3 months after the injury would recommend. If residual laxity (greater than grade 2) exist at the time of subsequent assessment, the surgery has to avoid further damage to articular cartilage and menisci.

Immediate ACL reconstruction for a top-level athlete with the same injury should be recommended.

When reconstruction is advised as the correct management of an ACL injury, there is a variety of options. Which type of graft, deciding on a single-bundle versus double- bundle reconstruction, choosing the placement of grafts, and whether to use the transtibial, additional anteromedial portal, or tibial tunnel-independent technique are choices that must be made. Each choice has its advantages and disadvantages, with the double-bundle strategy, proper placement of grafts, and the use of autografts found to result in better clinical outcomes and in greater patient satisfaction.

The selection of the best autograft tissue type remains controversial, with PT, HS tendon, and quadriceps tendon each having their proponents.

High-level evidence suggests that recreational patients can initially be treated nonoperatively or operatively for anterior cruciate ligament tears.

ACL reconstruction is recommended for patients with increased or persistent laxity after nonoperative treatment.

The return to sport after ACL reconstruction surgery should occur after a minimum of 9 months and should await the results of return to sport testing (patient performance in tests of symmetric quadriceps strength and Hop test).

Conflict of interest. The authors declare no conflict of interest. This publication has not been, is not and will not be the subject of commercial interest in any form.

\section{References}

1. Krosshaug T, Nakamae A, Boden BP. Mechanisms of anterior cruciate ligament injury in basketball video analysis of 39 cases. Am J Sports Med. 2007; 35:359-367.

2. Boden BP, Torg JS, Knowles DB. Video analysis of anterior cruciate ligament injury: abnormalities in hip and ankle kinematics. Am J Sports Med. 2009; 37:252-259.

3. Beynnon BD, Fleming BC. Anterior cruciate ligament strain invivo: a review of previous work. J Biomech. 1998; 31:519-525.

4. Benjaminse A, Gokeler A, Vand der Schans CP. Clinical diagnosis of an anterior cruciate ligament rupture: a meta-analysis. J Orthop Sports Phys Ther. 2006; 36:267-288.

5. Solomon DH, Simel DK, Bates DW. The rational clinical examination. Does this patient have a torn meniscus or ligament of the knee? Value of the physical examination. JAMA. 2001; 286:1610-1620.

6. Galway HR, MacIntosh DL. The lateral pivot shift: a symptom and sign of anterior cruciate ligament insufficiency. Clin Orthop. $1980 ; 147: 45-50$. 
7. Ostrowski JA. Accuracy of 3 diagnostic test for anterior cruciate ligament tears. J Athl Train. 2006; 41:120-121.

8. Noyes FR, Mooar PA, Matthew DS. The symptomatic anterior cruciate-deficient knee, part I. J Bone Joint Surg Am. 1983;65:154-162.

9. Sherman MF, Warren RF, Marshall JL. A clinical and radiographical analysis of 127 anterior cruciate insufficient knees. Clin Orthop. 1988; 227:229-237.

10. Spindler KP, Wright RW. Clinical practice. Anterior cruciate ligament tear. N Engl J Med. 2008; 359:2135-2142.

11. Chhabra A, Starman JS, Ferretti M. Anatomic, radiographic, biomechanical, and kinematic evaluation of the anterior cruciate ligament and its two functional bundles. J Bone Joint Surg Am. 2006; 88(suppl 4):2-10.

12. Steckel H, Vadala G, Davis D. 2D and 3D 3-Tesla magnetic resonance imaging of the double bundle structure in anterior cruciate ligament anatomy. Knee Surg Sports Traumatol Arthrosc. 2006;14: 1151-1158.

13. Starman JS, Vanbeek C, Armfield DR. Assessment of normal ACL double bundle anatomy in standard viewing planes by magnetic resonance imaging. Knee Surg Sports Traumatol Arthrosc. 2007; 15:493-499.

14. Fithian DC, Paxton EW, Stone ML. Prospective trial of a treatment algorithm for the management of the anterior cruciate ligament-injured knee. Am J Sports Med. 2005; 33:335-346.

15. Barrack RL, Bruckner JD, Kneisl J. The outcome of nonoperatively treated complete tears of the anterior cruciate ligament in active young adults. Clin Orthop Relat Res. 1990; 259:192-199.

16. Noyes FR, Barber SD, Mooar LA. A rationale for assessing sports activity levels and limitations in knee disorders. Clin Orthop Relat Res. 1989; 246:238-249.

17. Scavenius M, Bak K, Hansen S. Isolated total ruptures of the anterior cruciate ligament: a clinical study with long-term follow-up of 7 year. Scand J Med Sci Sports. 1999; 9: 114-119.

18. Wittenberg RH, Oxfort HU, Plafki C. A comparison of conservative and delayed surgical treatment of anterior cruciate ligament ruptures: a matched pair analysis. Int Orthop. 1998; $22: 145-148$.

19. Andernord D, Karlsson J, Fu FH, Samuelsson K. Timing of surgery of the anterior cruciate ligament. Arthroscopy 2013;29:1863-71.

20. Magnussen RA, Pedroza AD, Donaldson CT. Time from ACL injury to reconstruction and the prevalence of additional intraarticular pathology: is patient age an important factor? Knee Surg Sports Traumatol Arthrosc 2013;21:2029-34.

21. Sri-Ram K, Salmon LJ, Pinczewski LA.. The incidence of secondary pathology after anterior cruciate ligament rupture in $\mathbf{5 0 8 6}$ patients requiring ligament reconstruction. Bone Joint J 2013; 95B:59-64.

22. SheaKG, Careyj L, Richmond J. The American Academy of Orthopaedic Surgeons evidence-based guideline on management of anterior cruciate ligament injuries. J Bone Joint Surg Am 2015; 97:672-4.

23. Maletis GB, Chen J, Funahashi TT. Age-related risk factors for revision anterior cruciate ligament reconstruction: a cohort study of 21,304 patients from the Kaiser Permanente Anterior Cruciate Ligament Registry. Am J Sports Med 2016;44:331-6.

24. Recht MP, Piraino DW, Cohen MA, et al. Localized anterior arthrofibrosis (cyclops lesion) after reconstruction of the anterior cruciate ligament: MR imaging findings. Am J Roentgenol. 1995; $165: 383-385$.

25. Aune AK, Holm I, Risberg MA. Four-strand hamstring tendon autograft compared with patellar tendon-bone autograft for anterior cruciate ligament reconstruction: a randomized study with two-year follow-up. Am J Sports Med. 2001; 29:722-728.
26. Tuman JM, Diduch DR, Rubino LJ. Predictors for hamstring graft diameter in anterior cruciate ligament reconstruction. Am J Sports Med. 2007; 35:1945-1949.

27. DeAngelis JP, Fulkerson JP. Quadriceps tendon-a reliable alternative for reconstruction of the anterior cruciate ligament. Clin Sports Med. 2007; 26:587-596.

28. Lee S, Seong SC, Jo H. Anterior cruciate ligament reconstruction using quadriceps tendon autograft. J Bone Joint Surg Am. 2007;89 (suppl 3): 116-126.

29. Prodromos C, Joyce B, Shi K. A meta-analysis of stability of autografts compared to allografts after anterior cruciate ligament reconstruction. Knee Surg Sports Traumatol Arthrosc. 2007; 15:851-856. 30. Krych AJ, Jackson JD, Hoskin TL. A meta-analysis of patellar tendon autograft versus patellar tendon allograft in anterior cruciate ligament reconstruction. Arthroscopy. 2008; 24:292-298.

31. Sun K, Tian S, Zhang J. Anterior cruciate ligament reconstruction with BPTB autograft, irradiated versus non-irradiated allograft: a prospective randomized clinical study. Knee Surg Sports Traumatol Arthrosc. 2009; 17:464-474.

32. Ristanis S, Stergiou N, Patras K. Excessive tibial rotation during high-demand activities is not restored by anterior cruciate ligament reconstruction. Arthroscopy. 2005; 21:1323-1329.

33. Tashman S, Collon D, Anderson K. Abnormal rotational knee motion during running after anterior cruciate ligament reconstruction. Am J Sports Med. 2004; 32:975-983.

34. Adachi N, Ochi M, Uchio Y. Reconstruction of the anterior cruciate ligament: single versus double-bundle multistranded hamstring tendons. J Bone Joint Surg Br. 2004; 86:515-520.

35. Hamada M, Shino K, Horibe S. Single- versus bi-socket anterior cruciate ligament reconstruction using autogenous multiplestranded hamstring tendons with endoButton femoral fixation: a prospective study. Arthroscopy. 2001; 17:801-807.

36. Yasuda K, Kondo E, Ichiyama H. Anatomic reconstruction of the anteromedial and posterolateral bundles of the anterior cruciate ligament using hamstring tendon grafts. Arthroscopy. 2004; 20:1015-1025.

37. Mae T, Shino K, Miyama T. Single- versus two-femoral socket anterior cruciate ligament reconstruction technique: biomechanical analysis using a robotic simulator. Arthroscopy. 2001; 17:708-716. 38. Nishimoto K, Kuroda R, Mizuno K. Analysis of the graft bending angle at the femoral tunnel aperture in anatomic double bundle anterior cruciate ligament reconstruction: a comparison of the transtibial and the far anteromedial portal technique. Knee Surg Sports Traumatol Arthrosc. 2009; 17:270-276.

39. Yagi M, Wong EK, Kanamori A. Biomechanical analysis of an anatomic anterior cruciate ligament reconstruction. Am J Sports Med. 2002; 30:660-666.

40. Yamamoto Y, Hsu WH, Woo SL. Knee stability and graft function after anterior cruciate ligament reconstruction: a comparison of a lateral and an anatomical femoral tunnel placement. Am J Sports Med. 2004;32: 1825-1832.

41. Abebe ES, Moorman CT III, Dziedzic TS. Femoral tunnel placement during anterior cruciate ligament reconstruction: an in vivo imaging analysis comparing transtibial and 2-incision tibial tunnelindependent techniques. Am J Sports Med. 2009; 37:1904-1911.

42. Abebe ES, Kim JP, Utturkar GM. The effect of femoral tunnel placement on ACL graft orientation and length during in vivo knee flexion. J Biomechanics. 2011; 44:1914-1920.

43. Shelbourne KD, Klotz C. What I have learned about the ACL: utilizing a progressive rehabilitation scheme to achieve total knee symmetry after anterior cruciate ligament reconstruction. J Orthop Sci. 2006; 11:318-325.

44. Wright RW, Preston E, Fleming BC. A systematic review of anterior cruciate ligament reconstruction rehabilitation: part II: open versus closed 
kinetic chain exercises, neuromuscular electrical stimulation, accelerated rehabilitation, and miscellaneous topics. J Knee Surg. 2008; 21:225-234. 45. Risberg MA, Holm I, Myklebust G. Neuromuscular training versus strength training during first 6 months after anterior cruciate ligament reconstruction: a randomized clinical trial. Phys Ther. 2007; 87:737-750.

46. Moffat KL, Wang IN, Rodeo SA. Orthopedic interface tissue engineering for the biological fixation of soft tissue grafts. Clin Sports Med. 2009; 28:157-176.
47. Mahirogullari M, Ferguson CM, Whitlock PW. Freeze-dried allografts for anterior cruciate ligament reconstruction. Clin Sports Med. 2007; 26:625-637.

48. Lopez-Vidriero E, Goulding KA, Simon DA. The use of plateletrich plasma in arthroscopy and sports medicine: optimizing the healing environment. Arthroscopy. 2010; 26:269-278.

49. Weitzel PP, Richmond JC, Altman GH. Future direction of the treatment of ACL ruptures. Orthop Clin North Am. 2002; 33:653-661.

\title{
Відновлення передньої хрестоподібної зв'язки: проблеми, історія та майбутнє. Частина II
}

\author{
Зазірний I.M. ${ }^{1}$, Коструб 0.О. ${ }^{2}$
}

${ }^{1}$ Клінічна лікарня "Феофанія" Державного управління справами, м. Київ

2ДУ "Інститут травматології та ортопедії НАМН України", м. Київ

Резюме. Пошкодження передньої хрестоподібної зв'язки (ПХЗ) - одна з найбільш частих травм у спорті, яка має руйнівний вплив на рівень активності пацієнтів та якість їхнього життя. У пацієнтів, чии анамнез та результати клінічного обстеження свідчать про травму ПХЗ, МРТ показане для підтвердження діагнозу та визначення наявності супутніх ушкоджень. Дані, що свідчать про необхідність негайної реконструкиії ПХЗ, обмежені. Хірурги повинні обговорити з пащієнтом варіант структурованого прискореного курсу реабілітащії як альтернативу негайній реконструкиії. Якщо було обрано початкову стратегію реабілітацій, рекомендується послідовна оцінка функції колінного суглоба та функціонального відновлення в перші 3 місяці після травми. Якщо на момент подальшої оцінки існує залишкова нестабільність (більша за 2-й ступінь), операція необхідна для уникнення подальшого пошкодження суглобового хряща та меніска. У випадку якщо рекомендовано оперативне лікування при пошкодженні ПХЗ, існують різні варіанти. Тип трансплантата, одно- чи двопучкова техніка, місие розмімення трансплантатів та використання транстібіального доступу, додаткового антеромедіального порталу або техніки незалежного великогомілкового каналу - це вибір, який необхідно зробити. Кожен варіант має свої переваги та недоліки завдяки стратегії подвічного втручання, правильного розмімення трансплантатів та використання аутотрансплантатів, які впливають на клінічний результат та якість життя пацієнтів. Суперечливил залишається вибір найкращого типу тканин для аутотрансплантата: своїх прихильників має використання як сухожилків напівсухожилкового та кравецького м'язів, так і власної зв'язки надколінника, а також сухожилка чотириголового м'яза стегна.

ключові слова: передня хрестоподібна зв'язка; артроскопія; реконструкція; лікування.

\section{Восстановление передней крестообразной связки: проблемы, история и будущее. Часть II}

\section{Зазирный И.М. ${ }^{1}$, Коструб А.А. ${ }^{2}$}

${ }^{1}$ Клиническая больница “Феофания" Государственного управления делами, г. Киев

${ }^{2} Г$ "Институт травматологии и ортопедии НАМН Украины", г. Киев

Резюме. Повреждение передней крестообразной связки (ПКС) - одна из наиболее частых травм в спорте, оказывающая разрушительное воздействие на уровень активности пациентов и качество их жизни. Больным, чей анамнез и результаты клинического исследования свидетельствуют о травме ПКС, показано МРТ для подтверждения диагноза и определения наличия сопутствующих повреждений. Данные, свидетельствующие о необходимости немедленной реконструкиии ПКС, ограничены. Хирурги должны обсудить с пащиентом вариант структурированного ускоренного курса реабилитащии как альтернативу немедленной реконструкиии. Если была выбрана начальная стратегия реабилитации, рекомендуется последовательная оценка функиии коленного сустава и функиионального восстановления в первые 3 месяца после травмы. Если в момент последующей оценки сустава присутствует остаточная 
нестабильность (больше чем 2-й степени), необходимо оперативное вмешательство во избежание дальнейшего повреждения суставного хряща и мениска. В случае если рекомендуется оперативное лечение при повреждении ПКС, существуют различные варианты. Тип трансплантата, одно- или двухпучковая техника, место размещения трансплантата, использование транстибиального доступа, дополнительного антеромедиального портала или техники независимого большеберцового канала - выбор, который необходимо сделать. Каждый вариант имеет свои преимущества и недостатки: одно- или двухпучковая техника, правильное размещение трансплантата и использование аутотрансплантата влияют на клинический результат и качество жизни пачиентов. Спорным остается выбор наилучшего типа тканей для аутотрансплантата: своих сторонников илеет как использование сухожилия полусухожильной и портняжной мыши, так и использование собственной связки надколенника, а также сухожилия четырехглавой мышиы бедра.

Ключевые слова: передняя крестообразная связка; артроскопия; реконструкция; лечение.

\section{Відомості про авторів:}

Зазірний Ігор Михайлович - доктор медичних наук, керівник Центру ортопедї, травматології $і$ спортивної медицини клінічної лікарні "Феофанія" Державного управління правами, вул. акад. Заболотного, 21, Київ, 03143, Україна. ORCID: 00000001-7890-1499.

Коструб Олександр Олексійович - доктор медичних наук, професор, завідувач відділом спортивної та балетної травми ду "Інститут травматології та ортопедії НАМН України", вул. Бульварно-Кудрявська, 27, Київ, 01601, Украӥна. ORCID: 0000-00017925-9362.

\section{Information about autbors:}

Zazirnyi Ihor Mykhailovych - D.Med.Sc., head of the Center of Orthopedics, Traumatology and Sports Medicine of Clinical Hospital "Feofaniya" of the Agency of State Affairs, 21 Zabolotnobo Akademika St., Kyiv, 03143, Ukraine. ORCID: 0000-0001-7890-1499.

Kostrub Olexandr Oleksiiovych - D.Med.Sc., professor, head of the Department of Sports and Ballet Injuries, SI "Institute of Traumatology and Orthopedics of NAMS of Ukraine", 27 Bulvarno-Kudriavska St., Kyiv, 01601, Ukraine. ORCID: 0000-0001-7925-9362.

\section{Сведения об авторах:}

Зазирный Игорь Михайлович - доктор медииинских наук, руководитель Центра ортопедии, травматологии спортивноймедициныклинической больницы "Феофания" Государственного управления делами, ул. акад. Заболотного, 21, Киев, 03143, Украина. ORCID: 0000-0001-7890-1499.

Коструб Александр Алексеевич - доктор медицинских наук, профессор, заведующий отделом спортивной и балетной травмы ГУ "Институт травматологии и ортопедии НАМН Украины", ул. Бульварно-Кудрявская, 27, Киев, 01601, Украина. ORCID: 0000-0001-7925-9362.

Для кореспонденції: Зазірний Ігор Михайлович, керівник Центру ортопедії, травматології і спортивної медицини клінічної лікарні "Феофанія" Державного управління правами, вул. Дашавська, 25, кв. 14, 03056, Київ, Україна. Тел. +38(067)756-32-47. Факс: +38(044)259-67-68. E-mail: zazirny@ukr.net.

For correspondence: Zazirnyi Ihor M., head of the Center of Orthopedics, Traumatology and Sports Medicine of Clinical Hospital "Feofaniya" of the Agency of State Affairs, Apt. 14, 25 Dashavska St., 03056, Kyiv, Ukraine. Tel. +38(067)756-32-47. Fax. +38(044)259-67-68. E-mail: zazirny@ukr.net.

Для корреспонденции: Зазирный Игорь Михайлович, руководитель Центра ортопедии, травматологии и спортивной медицины клинической больницы “Феофания” Государственного управления делами, ул. Дашавская, 25, кв. 14, 03056, Киев, Украина. Тел. +38(067)756-32-47. Факс: +38(044)259-67-68. E-mail: zazirny@ukr.net. 